\title{
IMPLEMENTASI PROGRAM LITERASI MELALUI PEMBERIAN BINGO CARD UNTUK MENUMBUHKAN MINAT BACA PADA SISWA KELAS III SDN SELOREJO II
}

\author{
Evi Saraswati Liyah Agustinah', Rizka Nur Oktaviani \\ evisaraswatila04@gmail.com ${ }^{1}$, rizkanuroktaviani@ stkipbim.ac.id ${ }^{2}$, \\ PGSD, STKIP Bina Insan Mandiri Surabaya ${ }^{1}$ \\ PGSD, STKIP Bina Insan Mandiri Surabaya ${ }^{2}$
}

\begin{abstract}
Abstrak: Tujuan penelitian ini untuk (1) mendeskripsikan implementasi program literasi melalui pemberian bingo card untuk menumbuhkan minat baca pada siswa kelas III SDN Selorejo II, (2) mendeskripsikan minat baca pada siswa kelas III SDN Selorejo II setelah adanya bingo card. Penelitian ini menggunakan prosedur penelitian pendekatan kualitatif dengan jenis penelitian kualitatif deskriptif. Sumber data dan data penelitian ini meliputi sumber data primer dan data skunder. Teknik pengumpulan data yang digunakan wawancara, kuisioner, dan dokumentasi. Teknik analisis data melalui reduksi data, penyajian data, penarikan kesimpulan. Teknik pengujian keabsahan data melalui triangulasi, dan ketekunan pengamatan. Hasil penelitian menunjukkan bahwa; (1) implementasi program literasi melalui pemberian bingo card untuk menumbuhkan minat baca pada siswa kelas III SDN Selorejo II dilakukan dengan 3 tahap yakni; (a) tahap pembiasaan, dilakukan dengan menyuruh siswa untuk melakukan kegiatan membaca suatu hal yang tidak berkaitan dengan pelajaran selama 15 menit yang boleh dilakukan dari berbagai media; (b) tahap pengembangan, dilakukan melalui pemberian bingo card yang mengharusan siswa memilih kartu pertanyaan yang bertuliskan B, I, N, G, O didalam kantong yang tersedia; (c) tahap pembelajaran, siswa mengerjakan pertanyaan pada kartu yang telah diambil. Siswa mendapatkan hadiah jika sudah menyelesaikan pertanyaan hingga terkumpul huruf B, I, N, G, O. (2) minat baca siswa setelah adanya bingo card, diketahui mengalami pertumbuhan yang cukup bagus. Ini terbukti dari yang tadinya siswa tidak mau membaca menjadi mau untuk melakukan kegiatan membaca hingga 3-4 judul cerita karena tantangan yang ada pada bingo card.
\end{abstract}

Kata kunci: program literasi, bingo card, minat baca.

\section{LITERATION PROGRAM IMPLEMENTATION THROUGH GIVING BINGO CARD TO GROW READING INTEREST IN CLASS III STUDENTS OF SDN SELOREJO II}


Evi, Rizka. Implementasi Program Literasi melalui...

Abstract: The purpose of this study to (1) describe the implementation of literacy programs by giving a bingo card to develop a reading interest in class III SDN Selorejo II, (2) describe interest in student III SDN Selorejo after a bingo card. The study uses qualitative approach research procedures with descriptive types of qualitative research. This research's data and data covers primary and secondary data sources. The datacollecting techniques used were interviews, questionnaires, and documentaries. The data analysis techniques performed in this study through data reduction, data presentation, deduction drawing. The validity of data testing techniques ran through triangulation, and surveillance persistence. Research results entitled show that; (1) implementation of literacy programs through a bingo card to develop a reading interest in class III SDN Selorejo II, done on a three-stage basis; (a) the breeding stage, done by having student do with a 15-minute lesson from various media; $(b)$ the development stage, made through a gift of bingo cards that scented students select question cards that read B, I, N, G, O in the available pouch; $(c)$ the learning stage, students work on the questions on the cards that have been drawn. Students win prizes when they gather the letter $B, I, N, G, O$. (2) interest in reading students after a bingo card, it is known to experience considerable growth. This is evident from what students did not want to read to want to do a reading activity up to 3-4 story titles because of the challenge on the bingo card.

Keywords: literacy programs, bingo card, reading interest.

\section{PENDAHULUAN}

Program literasi atau gerakan literasi sekolah adalah suatu program yang sangat penting dan harus ada untuk diterapkan pada bidang pendidikan zaman sekarang. Sementara itu, menurut Kusumaningrum (2019:40), salah satu upaya sistematis dan berkesinambungan yang dapat digunakan untuk meningkatkan literasi siswa yakni melalui adanya program literasi. Manfaat yang dapat diperoleh dari program tersebut yakni mampu mengembangkan kemampuan siswa dalam hal membaca dan menulis. Adapun literasi sendiri menurut Budiharto, Triyono, \& Suparman (2018:156), adalah kemampuan mengakses, memahami, dan mengggunakan sesuatu dengan tepat melalui kegiatan membaca, menulis, menyimak atau berbicara. Gerakan literasi di sekolah dasar menurut Direktorat Jenderal Pendidikan Dasar dan Menengah Kementerian Pendidikan dan Kebudayaan (2017:13) menjelaskan bahwa salah satu aktivitas berliterasi adalah kegiatan membaca, yang merupakan kunci bagi kemajuan suatu pendidikan. Dengan adanya program yang dijalankan pemerintah terkait gerakan literasi sekolah (GLS) yang bertujuan untuk meningkatkan kemampuan literasi siswa yang diintegrasikan dengan kurikulum pembelajaran (Mutia, atmazaki, \& Nursaid, 2018:257). Dalam hal ini, 
Evi, Rizka. Implementasi Program Literasi melalui....

pemerintah mengusahakan kemmapuan siswa dalam beliterasi sesuai dengan Permendikbud Nomor 23 Tahun 2015 tentang petumbuhan budi pekerti.

Sementara itu, Teguh (2017:19) menyatakan bahwa tingkat keberhasilan setiap siswa di sekolah ataupun dalam kehidupan di masyarakat dapat menjadi peluang kesuksesan yang sangat baik dengan memiliki kemampuan membaca yang membudaya, karena semua proses belajar berdasar pada proses membaca. Kegiatan membaca merupakan jendela bagi masuknya berbagai macam ilmu pengetahuan yang ada. Hal ini sesuai dengan pendapat Salma \& Mudzanatun (2019) menyatakan bahwa dengan membaca seseorang dapat memperluas wawasan, mempertajam gagasan, meningkatkan kreativitas. Banyaknya siswa yang mendapatkan nilai tinggi di dalam suatu pelajaran tidak dapat menjadi pengukur keberhasilan suatu pendidikan, akan tetapi keberhasilan suatu pendidikan diukur seseorang dari banyaknya anak yang gemar membaca disuatu kelas. Siswa menjadi gemar membaca hal ini bertujuan untuk mencapai tujuan pendidikan yaitu untuk membuat setiap siswa memiliki budi pekerti yang luhur dan berakhlak mulia.

Apabila dikaitkan dengan sumber daya manusia di Indonesia saat ini menjadi sangat tidak kompetitif dikarenakan kurangnya penguasaan ilmu pengetahuan, yang diakibatkan oleh sangat rendahnya minat baca siswa. Menurut Maharani, laksono, \& Sukartiningsih, (2017), minat baca merupakan kekauatan pendorong agar tertarik, memperhatikan dan senang dengan kegiatan membaca sehingga sesorang mau melalkukan kegiatan tersebut dengan senang hati atas kemauan sendiri. Sementara itu, Ruslan \& Wibayanti (2019) menjelaskan bahwa jika siswa membaca sesuatu tanpa memiliki minat baca yang tinggi maka kegiatan membaca tersebut tidak akan dilakukan dengan sepenuh hati tetapi jika membaca dilakukan dengan keinginannya sendiri maka siswa tersebut akan membaca sepenuh hati (Ruslan \& Wibayanti (2019). Hal ini dibuktikan menurut Antoro (2017:5), bahwa hasil tes Programme for International Student Assessment (PISA) 2012 menempatkan Indonesia pada urutan ke-64 dari 65 negara yang disurvei mengenai literasi matematika, membaca, dan sains makin memperkuat asumsi mengenai rendahnya minat baca masyarakat di Indonesia. Terlebih, skor literasi membaca siswa di Indonesia masih jauh dibawah standar rata-rata 496 yakni hanya 396. Indonesia juga berada diperingkat ke-64 dari 72 negara pada survei terbaru PISA 2015 yang diumumkan pada 6 Desember 2016 (Antoro, 2017:9). 


\section{Evi, Rizka. Implementasi Program Literasi melalui...}

Berdasarkan hasil observasi yang telah dilakukan peneliti pada hari senin, tanggal 03 Februari 2020 di SDN Selorejo II menunjukkan bahwa rendahnya minat baca siswa disebabkan beberapa hal, salah satunya adalah malasnya siswa terhadap kegiatan membaca. Padahal terdapat berbagai media yang tersedia terutama media cetak yang dapat menjadi sumber bacaan untuk dapat digunakan siswa membaca. Contohnya media cetak (buku, majalah, koran, dll.), media elektronik (televisi dan radio), dan media digital (media internet). Untuk itu, peran serta seluruh pihak sangatlah penting dan berpengaruh untuk menumbuhkan minat baca pada siswa. Dalam hal menumbuhkan minat baca ataupun budaya literasi pada setiap siswa tentu tidak mudah, apalagi jika cara ataupun metode yang digunakan terlalu membosankan dan tidak bisa menarik minat satupun siswa untuk membaca.

Dalam menerapkan GLS setiap sekolah pada setiap jenjang wajib meningkatkan minat membaca dan sekolah sebagai pusat pembelajaran juga dapat diharapkan dapat menjadi pusat tumbuhnya motivasi belajar sepanjat hayat (Hastuti\& Lestari, 2018). Agar sekolah dapat menjadi tempat untuk mengembangkan budaya literasi diperlukannyaa strategi dalampelaksanaan GLS sesuai dengan arahan Kemendikbud (2019:29), yaitu ada 3 gerakan yaitu pembiasaan pengembangan dan pembelajaran. Pembiasaan ini bertujuan untuk menumbuhkan minat baca pada siswa, dan salah satu cara untuk menumbuhkan minat baca yakni melalui cara membaca 15 menit buku non pelajaran sebelum waktu pembelajaran dimulai. Kegiatan membaca 15 menit sebelum pelajaran ini dilakukan tanpa tagihan sampai minat baca pada siswa tumbuh, berkembang, dan sampai pada tahap gemar membaca. Pengembangan pembelajaran berbasis literasi dapat dilakukan dengan kegiatan non akademis, kegiatan tersebat dapat dilakukan dengan tagihan namun, tidak berhubungan/berkaitan dengan nilai. Contohnya yakni menulis sinopsis, mereview inti dari buku yang telah dibaca, kunjungan wajib keperpustakaan (jam literasi) dan masih banyak yang lainnya. Pelaksanaan pembelajaran berbais literasi ini, guru menerapkan strategi literasi dalam pelaksanaan pembelajaran (dalam seluruh mata pelajaran). Pembelajaran berbasis literasi juga membuat siswa membaca buku nonteks pelajaran yang dapat berupa buku pengetahuan umum, dan lain sebagainya sebagai syarat pelaksanaan kurikulum 2013.

Dalam abad ke 21 ini kemampuan berliterasi dapat disebut sebagai literasi informasi, karena kemampuan ini mencakup kemampuan untuk dapat memanfaatkan 
Evi, Rizka. Implementasi Program Literasi melalui...

sumber-sumber dalam bentuk cetak, visual, digital, dan auditori. Selain itu, Zainuri (dalam Ahmadi, Farid, dan Ibda, 2018:13) menjelaskan bahwa literasi juga dapat diartikan sadar/mengetahui terhadap teknologi, sadar terhadap informasi, mampu berfikir kritis, peka terhadap keadaan lingkungan, bahkan juga peka terhadap politik. Menurut pelakasanaan GLS di sekolah dasar dilakukan secara bertahap. Hal ini dipertimbangakan sesuai dengan kondisi dan kesiapan sekolah. Kesiapan ini meliputi kesiapan fisik sekolah berupa sarana prasaran literasi dan kesiapan warga sekolah yang terdiri dari guru, orang tua, siswa serta masyarakat (Rohim dan Rahmawati, 2020:3)

Dalam mewujudkan program gerakan literasi di sekolah-sekolah khususnya di sekolah dasar sebagaimana telah diterapkan dan dikembangkan peneliti melakukan sebuah penelitian dengan tujuan yaitu mendeskripsikan implementasi program literasi melalui pemberian bingo card untuk menumbuhkan minat baca pada siswa kelas III SDN Selorejo II dan mendeskripsikan minat baca pada siswa kelas III SDN Selorejo II setelah adanya bingo card. Peneliti melakukan penelitian di SDN Selorejo II yang beralamat di Dusun Pedes Desa Selorejo Kecamatan Sambeng Kabupaten Lamongan. Peneliti melakukan penelitian disekolah tersebut dikarenakan beberapa alasan salah satunya ialah banyaknya bahan bacaan yang termasuk kedalam media cetak yang tidak dimanfaatkan siswa untuk membaca (rendahnya minat baca siswa).

Menurut Clay, dan Ferguson (dalam Ahmadi dan Ibda, 2018: 22-24), komponen literasi informasi terdiri atas literasi dini, literasi dasar, literasi perpustakaan, literasi media, literasi teknologi, dan literasi visual. Pada penelitian ini, komponen literasi yang digunakan peneliti adalah literasi media (media literacy), karena media merupakan suatu alat yang begitu penting digunakan untuk kegiatan literasi dalam pendidikan di lingkungan sekolah, di lingkungan keluarga ataupun masyarakat. Tanpa adanya media maka kegiatan literasi tidak akan dapat terlaksana. Berbagai jenis media yang dapat dipergunakan siswa untuk kegiatan berliterasi contohnya seperti; media cetak, media elektronik, dan media digital yang berguna untuk memperluas pengetahuan dan informasi setiap warga sekolah terutama para siswa maupun masyarakat luas. Adapun dalam tujuan penelitian ini untuk (1) mendeskripsikan implementasi program literasi melalui pemberian bingo card untuk menumbuhkan minat baca pada siswa kelas III SDN Selorejo II, (2) mendeskripsikan minat baca pada siswa kelas III SDN Selorejo II setelah adanya bingo card. Adapun implementasi literasi di SDN Selorejo II dengan GLS dari arahan 
Evi, Rizka. Implementasi Program Literasi melalui...

Kemendikbud ada tiga tahap, yaitu: pembiasaan, pengembangan, dan pembelajaran. Dalam tahap pembiasaan ini siswa disuruh untuk membaca 5-15 menit sebelum pembelajaran. Dalam tahap pengembangan, peneliti memilih dengan menggunakan cara pemberian bingo card kepada siswa. Sementara itu, untuk tahap ketiga yaitu pembelajaran.

\section{METODE}

Pendekatan penelitian yang digunakan pada penelitian ini merupakan pendekatan kualitatif. Sementara itu, jenis penelitian yang digunakan adalah kualitatif deskriptif. Penelitian kualitatif dipergunakan dalam mendeskripsikan sesuatu, juga dapat dipergunakan untuk menganalisis suatu fenomena sosial, peristiwa, aktivitas sosial, sikap, kepercayaan, dan pemikiran orang, baik secara perorangan maupun dalam bentuk kelompok secara detail dan terperinci (Ghony dan Almanshur, 2012:89). Pendekatan kualitatif dengan menggunakan jenis penelitian kualitatif deskriptif. Tujuan digunakan pendekatan penelitian ini adalah untuk menyesuaikan rumusan masalah yang ada yakni mendeskripsikan implementasi program literasi melalui pemberian bingo card untuk menumbuhkan minat baca pada siswa kelas III SDN Selorejo II. Sumber data dari penelitian ini yakni: Sumber data primer dalam penelitian ini meliputi: Kepala Sekolah SDN Selorejo II sebagai informan, Guru SDN Selorejo II sebagai informan, dan Siswa kelas III SDN Selorejo II sebagai subjek penelitian sebanyak 4 siswa. Teknik pengumpulan data yang digunakan dalam pendekatan kualitatif deskriptif meliputi: Wawancara yang diajukan kepada Kepala Sekolah SDN Selorejo II dan Guru SDN Selorejo II. Dalam penelitian ini peneliti menggunakan wawancara tak terstruktur karena wawancara ini bersifat luwes, dan susunan pertanyaan yang sudah disediakan peneliti dapat diubah sesuai dengan kebutuhan dan kondisi yang dialami di lapangan saat menghadapi informan dengan cara tatap muka secara langsung (Ghony dan Almanshur, 2012:177). Kuisioner ditujukan untuk siswa kelas III SDN Selorejo II. Untuk memproses data dalam model Miles dan Huberman (dalam Ghony dan Almanshur, 2012:307) menjelaskan bahwa langkah-langkah dalam teknik analisis data penelitian kualitatif dapat melalui tiga proses, yaitu: (1.) reduksi data, dilakukan dengan cara memfokuskan atau pemilihan hal-hal yang dianggap penting oleh peneliti yang terlihat dari catatan-catatan berupa tulisan di tempat penelitian berlangsung. (2). penyajian data, disajikan melalui 
Evi, Rizka. Implementasi Program Literasi melalui... uraian singkat berbentuk teks naratif. (3). verifikasi/penarikan kesimpulan, menyimpulkan dan memilih data-data yang paling penting dari seluruh data yang sudah didapatkan dari proses penelitian yang telah dilakukan sehingga dapat memperoleh kesimpulan atau verifikasi. Teknik pengujian keabsahan data dilakukan melalui cara triangulasi. Berikut penjabaran dari teknik pengujian keabsahan data: 1. triangulasi Sumber, dalam pengujian kredibilitas data dapat dilakukan melalui pengecekan data yang diperoleh dari berbagai sumber. 2. triangulasi teknik pengumpulan data, teknik pengumpulan data dilakukan dari sumber yang sama tetapi melalui cara yang berbeda yakni meliputi wawancara, kuisioner dan dokumentasi. 3. ketekunan/keajengan pengamatan, pengujian keabsahan data yang dilakukan melalui ketekunan atau keajengan peneliti dalam pengamatan di lapangan maupun dilakukan secara daring dapat bertujuan untuk menemukan karakteristik yang berhubungan dengan permasalahan yang kemudian akan dijelaskan secara rinci.

\section{HASIL}

Hasil penelitian implementasi program literasi melalui pemberian bingo card untuk menumbuhkan minat baca pada siswa kelas III SDN Selorejo II berupa data dokumentasi implementasi program literasi melalui pemberian bingo card sedangkan untuk mendeskripsikan minat baca siswa kelas III SDN Selorejo II Kabupaten Lamongan setalah pemberian bingo card dapat dilihat dari hasil transkrip wawancara dan respon siswa. Adapun implementasi program literasi melalui pemberian bingo card sesuai dengan 3 tahap pelaksanaan GLS dapat dilihat melalui tabel berikut:

Tabel 2. Implementasi Program Literasi melalui Pemberian Bingo Card

\begin{tabular}{|c|c|l|}
\hline No. & $\begin{array}{c}\text { Tahap } \\
\text { Pelaksanaan }\end{array}$ & \multicolumn{1}{c|}{ Kegiatan } \\
\hline 1. & $\begin{array}{c}\text { Tahap } \\
\text { Pembiasaan }\end{array}$ & $\begin{array}{l}\text { Tahap pembiasaan dilakukan sebelum siswa memulai pembelajaran. } \\
\text { Pembiasaan dilakukan dengan cara menyuruh siswa untuk melakukan } \\
\text { kegiatan membaca selama kurang lebih 15 menit, yakni dalam penelitian } \\
\text { ini dimulai setelah peneliti melakukan perkenalan kepada siswa yakni } \\
\text { mulai pukul 07.10 WIB hingga pukul 07.25 WIB yang boleh dilakukan } \\
\text { dengan membaca dari berbagai media seperti media cetak (buku, koran } \\
\text { dll) media visual (televisi, radio) dan media digital (internet). }\end{array}$ \\
\hline 2. & $\begin{array}{l}\text { Tahap pengembangan dilakukan peneliti melalui cara pemberian bingo } \\
\text { card. Bingo card sendiri memiliki desain yang menarik yang berisikan } \\
\text { tantangan seputar membaca yang harus dilakukan oleh setiap siswa. } \\
\text { Kemudian peneliti memberikan arahan terkait aturan penggunaan bingo }\end{array}$ \\
\hline
\end{tabular}


Evi, Rizka. Implementasi Program Literasi melalui...

\begin{tabular}{|c|c|c|}
\hline & & $\begin{array}{l}\text { card. . Peneliti mulai untuk memberikan bingo card yang berupa kartu } \\
\text { tantangan yang berada didalam kantong-kantong yang telah disediakan } \\
\text { peneliti sebelumnya. Kemudian, siswa bergantian dipersilahkan untuk } \\
\text { mengambil } 5 \text { kartu yang berisikan pertanyaan didalam kantong yang } \\
\text { harus terdiri dari huruf B, I, N, G, O. Siswa diperbolehkan mengambil } \\
\text { kartu dikantong manapun yang diinginkan. }\end{array}$ \\
\hline 3. & $\begin{array}{c}\text { Tahap } \\
\text { Pembelajaran }\end{array}$ & $\begin{array}{l}\text { Tahap ini dilakukan dengan mengerjakan pertanyaan yang ada pada } \\
\text { kartu-kartu yang telah diambil dari kantong-kantong bingo pada tahap } \\
\text { pengembangan. Pada tahap ini siswa diharuskan menyelesaikan tantangan } \\
\text { dengan membaca cerita yang berasal dari berbagai media seperti media } \\
\text { cetak antara lain buku, koran, dll. Dalam kartu pertanyaan bingo card, } \\
\text { terdapat juga perintah untuk menerjemahkan kata berbahasa asing } \\
\text { kedalam bahasa Indonesia. Untuk itu, siswa diharuskan untuk } \\
\text { menerjemahkan kata tersebut dengan menggunakan kamus yang juga } \\
\text { termasuk kedalam media cetak. Siswa juga diperbolehkan membaca lewat } \\
\text { media digital (internet), maupun media visual (televisi dan radio). } \\
\text { Namun, pada tahap ini siswa kebanyakan lebih memilih untuk melakukan } \\
\text { kegiatan membaca melalui buku yang telah disediakan oleh peneliti } \\
\text { sebelumnya. }\end{array}$ \\
\hline
\end{tabular}

Untuk mendeskripsikan minat baca siswa kelas III SDN Selorejo II Lamongan

dapat dilihat dari trankrip wawancara kepala sekolah dan guru kelas III serta hasil respon siswa kelas III terhadap implementasi literasi melalui pemberian bingo card. Adapun hasil wawancara guru dan kepala sekolah yang diperoleh peneliti melalui daring dikarenakan saat ini terjadi pandemi Covid-19 dapat dilihat pada tabel berikut:

Tabel 3. Hasil Wawancara Guru dan Kepala Sekolah

\begin{tabular}{|c|c|c|c|}
\hline No & Panduan Pertanyaan & Jawaban dari Guru & Jawaban dari Kepala Sekolah \\
\hline 1. & $\begin{array}{c}\text { Sejak kapan program literasi } \\
\text { diimplementasikan di SDN } \\
\text { Selorejo II? }\end{array}$ & $\begin{array}{l}\text { Program literasi di } \\
\text { SDN Selorejo II } \\
\text { diimplementasikan } \\
\text { sekitar tahun } 2015\end{array}$ & $\begin{array}{l}\text { Kalau untuk program literasi di } \\
\text { SDN Selorejo II, karena saya } \\
\text { baru di tugaskan disini jadi saya } \\
\text { hanya tinggal melanjutkan } \\
\text { program yang sudah ada saja. } \\
\text { Yang jelas, program ini sudah } \\
\text { ada sejak tahun 2015." }\end{array}$ \\
\hline 2. & $\begin{array}{c}\text { Apa saja program literasi yang } \\
\text { ada di SDN Selorejo II? Jika } \\
\text { ada, bagaimana teknik } \\
\text { pelaksanaannya }\end{array}$ & $\begin{array}{c}\text { Adanya program wajib } \\
\text { baca yang dilakukan } \\
\text { sebelum masuk kelas, } \\
\text { dan juga membaca di } \\
\text { sela-sela waktu } \\
\text { istirahat siswa } \\
\end{array}$ & $\begin{array}{l}\text { Program literasi yang ada yakni } \\
\text { wajib baca sebelum masuk kelas } \\
\text { dan membaca saat waktu } \\
\text { istirahat. Untuk pelaksanaannya } \\
\text { hanya sekedar menyuruh siswa } \\
\text { membaca saja. }\end{array}$ \\
\hline 3. & $\begin{array}{c}\text { Menurut Bapak/Ibu efektifkah } \\
\text { program literasi tersebut } \\
\text { dilakukan? }\end{array}$ & $\begin{array}{l}\text { Tidak terlalu efektif, } \\
\text { karena memang } \\
\text { kurangnya perhatian } \\
\text { dan motivasi yang } \\
\text { diberikan kepada siswa } \\
\text { agar mau membaca }\end{array}$ & $\begin{array}{l}\text { untuk saat ini program tersebut } \\
\text { saya rasa belum efektif karena } \\
\text { masih kurangnya perhatian guru } \\
\text { kelas terhadap minat baca } \\
\text { siswa.dan kurangnya kesadaran } \\
\text { siswa mengenai pentingnya } \\
\text { membaca. Jadi siswa itu } \\
\text { menunggu di suruh membaca } \\
\text { dulu oleh gurunya. Sedangkan } \\
\text { guru tidak bisa setiap hari untuk } \\
\text { selalu mengarahkan siswa untuk } \\
\text { membaca }\end{array}$ \\
\hline
\end{tabular}


Evi, Rizka. Implementasi Program Literasi melalui...

\begin{tabular}{|c|c|c|c|}
\hline 4. & $\begin{array}{l}\text { Media apa saja yang tersedia di } \\
\text { SDN Selorejo II yang dapat } \\
\text { digunakan siswa untuk kegiatan } \\
\text { membaca? }\end{array}$ & $\begin{array}{l}\text { Untuk saat ini } \\
\text { medianya hanya } \\
\text { sebatas buku-buku di } \\
\text { perpustakaan }\end{array}$ & $\begin{array}{l}\text { Untuk saat ini media yang } \\
\text { tersedia berupa buku-buku di } \\
\text { perpustakaan. }\end{array}$ \\
\hline 5. & $\begin{array}{c}\text { Apakah ada } \\
\text { reward/penghargaan bagi siswa } \\
\text { yang gemar membaca? }\end{array}$ & Belum ada & Belum ada \\
\hline 6. & $\begin{array}{c}\text { Apa saja yang menjadi faktor } \\
\text { pendukung dan penghambat } \\
\text { program literasi di SDN } \\
\text { Selorejo II? }\end{array}$ & $\begin{array}{c}\text { Untuk faktor } \\
\text { pendukungnya ya } \\
\text { banyaknya buku-buku } \\
\text { yang tersedia } \\
\text { diperpustakaan yang } \\
\text { dapat digunakan siswa } \\
\text { untuk membaca. Untuk } \\
\text { faktor penghambatnya } \\
\text { sendiri ya masih } \\
\text { rendahnya minat baca } \\
\text { siswa mbak, karena } \\
\text { mereka lebih suka } \\
\text { bermain dari pada } \\
\text { membaca buku }\end{array}$ & $\begin{array}{l}\text { Kalau faktor pendukungnya itu } \\
\text { ya sudah tersedianya berbagai } \\
\text { macam koleksi buku-buku yang } \\
\text { cukup banyak. Untuk faktor } \\
\text { penghambatnya sendiri ya } \\
\text { masih dari rendahnya minat } \\
\text { baca siswa, dan juga memang } \\
\text { pengelolaan perpustakaan yang } \\
\text { masih seadanya, dan belum } \\
\text { adanya tenaga ahli yang berasal } \\
\text { dari lulusan bidang tersebut. }\end{array}$ \\
\hline 7. & $\begin{array}{l}\text { Bagaimana pendapat Bapak/Ibu } \\
\text { tentang implementasi program } \\
\text { literasi melalui pemberian bingo } \\
\text { card di SDN Selorejo II? }\end{array}$ & $\begin{array}{c}\text { Sangat bagus, apalagi } \\
\text { media yang digunakan } \\
\text { sangat menarik dan } \\
\text { berwarna-warni }\end{array}$ & $\begin{array}{l}\text { Saya rasa cukup bagus, supaya } \\
\text { ada inovasi dalam program } \\
\text { literasi di sekolah. Agar siswa- } \\
\text { siswi lebih tertarik untuk } \\
\text { membaca. }\end{array}$ \\
\hline 8. & $\begin{array}{c}\text { Bagaimana rencana Bapak/Ibu } \\
\text { ke depan untuk meumbuhkan } \\
\text { minat baca siswa di SDN } \\
\text { Selorejo II? }\end{array}$ & $\begin{array}{c}\text { Untuk meumbuhkan } \\
\text { minat baca siswa, } \\
\text { kedepannya } \\
\text { mengimplementasikan } \\
\text { kembali program } \\
\text { literasi melalui } \\
\text { pemberian bingo card } \\
\text { karena terdapat } \\
\text { tantangan-tantangan } \\
\text { berupa pertanyaan agar } \\
\text { siswa mau membaca } \\
\text { dan tidak bermain } \\
\text { terus. }\end{array}$ & $\begin{array}{l}\text { Untuk kedepannya saya ingin } \\
\text { memberikan setiap siswa kartu } \\
\text { kunjungan perpustakaan, dan } \\
\text { bagi siswa yang paling banyak } \\
\text { catatan berkunjung ke } \\
\text { perpustakaan akan mendapatkan } \\
\text { hadiah }\end{array}$ \\
\hline
\end{tabular}

Adapun hasil respon siswa yang diperoleh dapat dilihat pada tabel 4 berikut ini:

Tabel 4. Hasil Respon Siswa Implementasi Program Literasi Melalui Pemberian Bingo Card untuk Menumbuhkan Minat Baca pada Siswa Kelas III SDN Selorejo II

\begin{tabular}{|c|l|c|c|c|c|}
\hline No. & \multicolumn{1}{|c|}{ Pertanyaan } & SS & S & R & TS \\
\hline 1. & $\begin{array}{l}\text { Saya senang membaca lewat media cetak (buku, koran, } \\
\text { majalah, dll). }\end{array}$ & 4 & & & \\
\hline 2. & Saya senang membaca lewat media digital (Internet) & 2 & 2 & & \\
\hline 3. & Saya senang dengan adanya pemberian bingo card. & 4 & & & \\
\hline 4. & Pertanyaan bingo card mudah dipahami. & 4 & & & \\
\hline
\end{tabular}


Evi, Rizka. Implementasi Program Literasi melalui...

\begin{tabular}{|c|c|c|c|c|c|}
\hline 5. & Bingo card sangat menarik dan bagus. & 4 & & & \\
\hline 6. & Saya menyelesaikan tantangan bingo card tanpa paksaan. & 4 & & & \\
\hline 7. & Saya tidak bosan dengan adanya bingo card. & 4 & & & \\
\hline 8. & $\begin{array}{l}\text { Saya merasa tertantang untuk menyelesaikan tantangan dalam } \\
\text { bingo card. }\end{array}$ & 3 & 1 & & \\
\hline 9. & $\begin{array}{l}\text { Saya mampu menyelesaikan tantangan bingo card dengan } \\
\text { cepat. }\end{array}$ & 4 & & & \\
\hline 10. & $\begin{array}{l}\text { Saya tidak memiliki kendala yang berarti saat menyelesaikan } \\
\text { tantangan bingo card. }\end{array}$ & & 2 & 1 & 1 \\
\hline 11. & $\begin{array}{l}\text { Saya sangat senang di dampingi oleh orang tua/guru saat } \\
\text { membaca. }\end{array}$ & 4 & & & \\
\hline 12. & Saya sering membaca di dalam hati. & 3 & 1 & & \\
\hline 13. & Saya sangat fokus membaca. & 3 & 1 & & \\
\hline 14. & $\begin{array}{l}\text { Saya mengembalikan buku yang selsai saya baca ke } \\
\text { tempatnya kembali. }\end{array}$ & 4 & & & \\
\hline 15. & Saya tidak menyontek jawaban teman. & 4 & & & \\
\hline 16. & $\begin{array}{l}\text { Saya merasa senang mendapatkan reward/nilai tinggi setelah } \\
\text { menyelesaikan bingo card. }\end{array}$ & 4 & & & \\
\hline
\end{tabular}

Keterangan : SS (sangat setuju); S (setuju); R (ragu ragu); TS (tidak setuju)

\section{PEMBAHASAN}

Pada pembahasan kali ini peneliti akan mengintegrasikan temuan yang ada di lapangan kemudian menyamakan dengan teori-teori yang ada pada kajian pustaka sebelumnya dalam mendeskripsikan impelementasi program literasi melalaui pemberian bingo card untuk menumbuhkan minat baca pada siswa dan mendeskripsikan minat baca setelah adanya pemberian bingo card,

\section{Implementasi program literasi melalui pemberian bingo card untuk menumbuhkan minat baca pada siswa}

Berdasarkan tabel 3 hasil transpkrip wawancara guru dan kepala sekolah bahwa kegiatan literasi sudah diimplementasikan pada tahun 2015. Program literasi pada SDN Selorejo II yaitu hanya dalam tahap pembiasaan saja yaitu wajib baca yang dilakukan sebelum masuk kelas, dan juga membaca di sela-sela waktu istirahat siswa, namun program tersebut belum efektif dikarenakan kurangnya perhatian dan motivasi guru kelas yang diberikan kepada siswa kurangnya kesadaran siswa mengenai pentingnya membaca. Jadi siswa itu menunggu disuruh membaca dulu oleh gurunya. Selain itu, didukung oleh beberapa faktor penghambat dalam hal implementasi program literasi di SDN Selorejo II 
Evi, Rizka. Implementasi Program Literasi melalui...

yaitu rendahnya minat membaca, sistem pengelolaan perpustakaan masih seadanya dan belum adanya tenaga ahli yang berasal dari lulusan bidang tersebut yakni pustakawan.

Sementara itu, berdasarkan tabel 2 implementasi program literasi melalui pemberian bingo card untuk menumbuhkan minat baca pada siswa kelas III SDN Selorejo II dilakukan melalui beberapa tahap yakni meliputi:

\section{Tahap Pembiasaan}

Kegiatan ini dilakukan untuk membuat minat baca setiap siswa dapat tumbuh secara perlahan hingga mengarah pada siswa yang gemar membaca. Dalam tahap pembiasaan yang dilakukan dengan cara menyuruh siswa untuk membaca selama 15 menit sebelum siswa memulai pembelajaran. Hal ini sesuai dengan Peraturan Menteri Pendidikan dan Kebudayan Nomor 23 Tahun 2015 mewajibkan para siswa untuk membaca minimal 15 menit sebelum melakukan kegiatan belajar dan mengajar disekolah setiap hari ini. Menurut Setiawan dan Dewayani (2019:1), dengan 15 menit membaca setiap hari, seorang siswa akan membaca selama 5.475 menit setiap tahun, 91 jam 15 menit dan terpajan kepada sekitar 1.000.000 sehingga pembendaharaan kosakata setiap 15 menit akan terpajan 1.642.500 kata. atau tidak memiliki kendala yang berarti. Dalam penelitian terdapat kendala seperti ketidaktahuan siswa kapan harus berhenti membaca. Meskipun peneliti sudah memberikan informasi bahwa kegiatan membaca pada tahap pembiasaan ini dilakukan selama 15 menit namun siswa tetap melanjutkan membaca meskipun waktu yang telah ditentukan sudah habis. Untuk itu, peneliti menyuruh siswa untuk berhenti membaca dan mengambil buku yang telah siswa baca.

\section{Tahap Pengembangan}

Pada tahap pengembangan yang dilakukan peneliti yaitu pemberian bingo card. Bingo card sendiri memiliki desain yang menarik yang berisikan tantangan seputar membaca yang harus dilakukan oleh setiap siswa. Menurut Silberman (dalam Hapsari dan Wicaksono, 2012:4), bingo adalah suatu permainan berupa tabel yang bernomor, siswa dapat dikatakan menang jika mampu untuk memperoleh lima deret huruf B-I-N-G-O secara horizontal, vertikal, maupun diagonal dengan menjawab setiap soal dengan benar maka dia berhak untuk menulis kan kata $\mathrm{B}-\mathrm{I}-\mathrm{N}-\mathrm{G}-\mathrm{O}$ dan berhak mendapatkan poin karena berhasil menjawab 5 pertanyan dengan benar. Sementara itu, card berasal dari bahasa inggris yang memiliki arti "kartu". Kartu 
Evi, Rizka. Implementasi Program Literasi melalui... sendiri dalam kamus besar Bahasa Indonesia berarti kertas tebal, berbentuk persegi panjang yang dapat digunakan untuk berbagai keperluan. Dalam penelitian ini bingo card adalah suatu kartu berupa tantangan yang berisi pertanyaan yang jawabannya harus dicari dengan cara membaca dari berbagai media yang tersedia, jika siswa dapat memperoleh lima kartu yang bertuliskan huruf B-I-N-G-O dengan cara menjawab pertanyaan dengan benar maka, siswa berhak mendapatkan reward. Beberapa kelebihan yang dimiliki oleh kartu bingo adalah pertanyaan yang mudah dipahami oleh setiap siswa, mudah diterapkan, dapat membuat siswa menjadi tertantang dengan tantangan yang diberikan di dalam bingo card, dan siswa menjadi lebih aktif untuk membaca. Sementara itu, kekurangannya adalah apabila pemberian bingo card dilakukan tanpa persiapan yang matang maka tujuan untuk menumbuhkan minat baca siswa tidak akan dapat tercapai secara maksimal.

Dalam pelaksanaannya siswa ditunjukkan papan bingo terdapat kantong-kantong yang berisikan kartu tantangan yang telah disediakan. Setelah itu, siswa bergantian dipersilahkan untuk mengambil 5 kartu yang berisikan pertanyaan didalam kantong yang harus terdiri dari huruf B, I, N, G, O. Siswa diperbolehkan mengambil kartu dikantong manapun yang diinginkan. Sebelum memulai menjawab pertanyaan yang ada didalam kartu yang telah diambil oleh siswa, peneliti terlebih dahulu memberi penjelasan kepada siswa mengenai aturan-aturan yang ada agar siswa nantinya tidak mengalami kesulitan ketika menyelesaikan tantangan yang ada pada bingo card tersebut. Aturan yang ada seperti siswa hanya boleh menyelesaikan tantangan bingo card yang berupa pertanyaan diwaktu yang ditentukan saja, seperti waktu sebelum pelajaran dimulai, waktu istirahat, waktu luang, maupun waktu yang telah ditentukan oleh guru saja. Siswa tidak diperbolehkan menyelesaikan tantangan diwaktu kegiatan belajar mengajar sedang berlangsung. Hasil yang didapat dari tahap pengembangan adalah dengan adanya bingo card yang dibuat semenarik mungkin oleh peneliti, membuat siswa menjadi senang dan tidak bosan untuk ikut menyelesaikan tantangan seputar membaca. Kendala yang terjadi pada tahap pengembangan adalah siswa gugup dan tidak mau bertanya kepada peneliti jika penjelasan yang diberikan dirasa kurang dipahami sehingga, membuat siswa saat mengambil kartu didalam kantong secara bergiliran terjadi sangat lama. Dikarenakan siswa kebingungan harus mengambil kartu yang terletak dikantong yang mana saja. Untuk itu, selama siswa 
Evi, Rizka. Implementasi Program Literasi melalui... mengambi 1 kartu bergiliran, peneliti membantu siswa yang belum paham dengan memberikan petunjuk mengenai kartu-kartu mana yang harus diambil oleh siswa

\section{Tahap Pembelajaran}

Tahap ini dilakukan dengan mengerjakan pertanyaan yang ada pada kartu-kartu yang telah diambil dari kantong-kantong bingo pada tahap pengembangan. Pada tahap ini siswa diharuskan menyelesaikan tantangan dengan membaca cerita yang berasal dari berbagai media seperti media cetak antara lain buku, koran, dll. Dalam kartu pertanyaan bingo card, terdapat juga perintah untuk menerjemahkan kata berbahasa asing kedalam bahasa Indonesia. Untuk itu, siswa diharuskan untuk menerjemahkan kata tersebut dengan menggunakan kamus yang juga termasuk kedalam media cetak. Siswa juga diperbolehkan membaca lewat media digital (internet), maupun media visual (televisi dan radio). Namun, pada tahap ini siswa kebanyakan lebih memilih untuk melakukan kegiatan membaca melalui buku yang telah disediakan oleh peneliti sebelumnya.

Siswa lebih memilih membaca melalui buku dikarenakan jika membaca menggunakan media digital seperti internet akan memakan waktu yang sangat lama untuk dapat membuka link berbagai macam cerita dikarenakan susahnya jaringan yang tersedia. Jika jawaban yang diselesaikan dirasa benar dari kartu yang bertuliskan huruf B, I, N, G, O maka, siswa berhak mendapatkan hadiah yang telah disediakan peneliti sebelumnya. Program literasi yang dilakukan dengan cara melalui pemberian bingo card ini, merupakan program literasi yang sesuai dengan program literasi Kemendikbud yang tahapannya meliputi tahap pembiasaan, yang pada tahap ini siswa diarahkan untuk membaca buku non pelajaran seperti buku cerita selama 15 menit. Program literasi melalui pemberian bingo card ini juga sesuai dengan gerakan literasi sekolah menurut Abidin (2017: 279), mengenai upaya yang ditempuh agar siswa memiliki minat baca yang tinggi melalui pembiasaan membaca lewat suatu gerakan sosial.

\section{Minat Baca Siswa Setelah Adanya Bingo Card}

Dengan adanya pemberiaan bingo card dapat dilihat minat baca siswa mengalami pertumbuhan dan meningkat hal ini sesuai pada tabel 3 dari hasil wawancara kepala 
Evi, Rizka. Implementasi Program Literasi melalui...

sekolah dan guru kelas III bahwa media bingo card ini sangat menarik dan berwarna warni selain itu adanya inovasi dalam program literasi sehingga siswa tertarik untuk membaca. Hal ini juga dibuktikan siswa yang tadinya jarang membaca dan hampir tidak pernah membaca menjadi mau membaca dengan adanya bingo card yang menarik dan berwarna warni. Siswa juga mengurangi bermain game dan memilih untuk melakukan kegiatan membaca tanpa mengalami paksaan.ini membuat guru menjadi senang dikarenakan dengan adanya bingo card siswa menjadi mau untuk melakukan kegiatan membaca. Sementara itu, hasil respon 4 siswa terkait angket/kuesioner yang berisi 16 pertanyaan telah diisi dengan baik dengan hasil yang memuaskan.

Berdasarkan tabel 4, semua siswa sangat setuju jika membaca lewat media cetak seperti (buku, koran, dan majalah) namun ada 2 siswa yang ragu-ragu membaca lewat media digital (internet) hal ini disebakan siswa kesulitan dan membutuhkan waktu yang lama untuk membuka link yang sudah dibagikam. Dengan adanya media bingo card ini semua siswa sanat setuju menyatakan bahwa bingo card ini menarik dan bagus. Selain itu semua siswa merasa senang dan tidak bosan pada saat diberikan bingo card, pada saat membaca pertanyaan pada bingo card semua siswa sangat setuju mudah dipahami. Selain itu, semua siswa setuju bahwa memiliki keinginan untuk menyelesaikan tantangan seputar membaca yang berisi pertanyaan yang jawabannya harus diisi melalui membaca cerita terlebih dahulu dari berbagai media, seperti media cetak, media digital, dan media visual tanpa paksaan dan siswa juga dapat membaca 3-4 judul cerita sekaligus dari buku cerita maupun internet. Hal ini dikarenakan pada setiap kartu pertanyaan yang diambil siswa dari kantong-kantong yang tersedia harus diisi dengan membaca cerita dari judul yang berbeda untuk mengisi setiap pertanyaan yang ada. Selain itu, pada point ke-9 menyatakan bahwa seluruh siswa sangat setuju dapat menyelesaikan tantangan bingo card dengan cepat dan hanya membutuhkan waktu selama kurang dari 1 hari.

Sementara itu, pernyataan Saya tidak memiliki kendala yang berarti saat menyelesaikan tantangan bingo card". Pernyataan ini membuat 2 siswa menjawab tidak setuju, 1 siswa menjawab setuju dan 1 siswa menjawab sangat setuju. Dalam hal ini siswa menjawab memang mengalami kendala saat menyelesaikan tantangan. Untuk itu, peneliti membatu siswa-siswa yang kurang paham dalam pertanyaan dan lain sebagainya. Dalam kegiatan membaca semua siswa sangat setuju apabila didamping guru/orang tua. Selain itu siswa sangat setuju apabila membaca dalam hati dan fokus dalam membaca . ketika 
Evi, Rizka. Implementasi Program Literasi melalui... mengembalikan buku yang sudah dibaca semua siswa sangat setuju untuk mengembalikan ketempatnya. Pada saat menjawab pertanyaan sesuai dengan tantangan tiap kartu seluruh siswa sangat setuju tidak mencontek jawaban teman, hal ini dikarenakan setiap buku dan judul cerita yang dibaca setiap siswa berbeda satu dengan yang lain, untuk itu seluruh siswa tidak dapat menyontek jawaban satu dengan yang lain meskipun memiliki pertanyaan yang sama. Dengan adanya pemberian reward/niai tinggi setelah menyelesaikan bingo card seluruh siswa sangat setuju dan hal ini tampak siswa memang terlihat sangat senang saat mendapatkan reward berupa hadiah dari peneliti saat sudah menyelesaikan tantangan bingo card.

Sejalan dengan teori menurut Yusuf (dalam Sudarsana, Undang dan bastiano, 2017:4.42), minat adalah kesenangan untuk memperhatikan suatu objek yang berlangsung terus menerus karena mengarapkan dapat memperoleh suatu manfaat. Didukung dengan teori Susanto (2013:57), menjelaskan bahwa minat yakni diartikan sebagai suatu kegemaran, suatu kesukaan, atau bisa juga diartikan sebagai suatu kesenangan individu oleh sesuatu. Siswa disini juga memiliki kesenangan untuk membaca terus-menerus karena adanya bingo card yang memiliki desain yang menarik perhatian siswa. Adanya tantangan berupa pertanyaan yang harus diselesaikan siswa dengan cara membaca lewat berbagi media seperti buku dan internet diharapkan siswa mendapatkan hal-hal yang penting dari suatu cerita yang dibaca agar dapat digunakan untuk mengisi pertanyaan dalam kartu yang jawabannya harus dicari dengan melakukan kegiatan membaca dari berbagai media.

Sementara itu, teori yang dikemukaan Kalida (2015:253) menjelaskan bahwa minat baca bisa dimaknai sebagai dorongan hati yang kuat untuk membaca. Ini terbukti dari hasil kuisioner yang diberikan peneliti kepada siswa selama penelitian sebelumnya, bahwa siswa benar-benar menyelesaikan tantangan bingo card yang berupa pertanyaan yang jawabannya harus dilakukan dengan melakukan kegiatan membaca dilakukan oleh siswa tanpa paksaan. Siswa juga sangat membaca dengan cara melalui pemberian bingo card ini karena merasa tertantang. Sementara itu, teori yang memaparkan teknik-teknik yang dapat digunakan untuk membaca ekstensif menurut Broughton (dalam Mulyati, dkk. 2016:4.19) yakni survei reading (membaca survei), skimming (membaca sekilas), dan superficial reading (membaca dangkal). 


\section{Evi, Rizka. Implementasi Program Literasi melalui...}

Dalam hal ini siswa diharuskan membaca menggunakan tingkatan membaca ekstensif karena siswa harus mengakses informasi sebanyak-banyaknya dengan waktu yang sangat singkat untuk dapat menyelesaikan tantangan bingo card, dengan tingkatan ini juga siswa dapat membaca dengan cakupan yang lebih luas yang dapat disesuaikan dengan keinginan siswa. Dalam hal ini siswa diketahui memang melakukan kegiatan membaca sangat cepat dan hanya memperhatikan hal-hal yang dirasa penting dan dibutuhkan untuk mengisi pertanyaan pada bingo card. Dalam setengah hari siswa dapat menyelesaikan kegiatan membaca hinga 3-4 judul cerita dari media apapun yang diinginkan beserta judul cerita yang sesuai dengan keinginan masing-masing.

Implementasi program literasi melalui pemberian bingo card ini dirasa benarbenar sangat bagus digunakan sebagai cara baru untuk menumbuhkan minat baca pada setiap siswa. Adanya bingo card membuat siswa benar-benar tertarik dan mau untuk membaca dari bermacam-macam media seperti media cetak maupun media digital yang tersedia. Bingo card membuat siswa sangat senang menjadi mau membaca tanpa paksaan dari pihak luar dan siswa juga tidak merasa bosan. Minat baca siswa setelah adanya bingo card dirasa memanng benar-benar mengalami perkembangan yang cukup bagus. Adanya bingo card siswa yang tadinya tidak mau membaca menjadi mau untuk membaca hingga mampu membaca hingga 3-4 judul cerita dalam waktu kurang dari satu hari. Gurupun menjadi senang karena siswa siswi yang tidak mau membaca sama sekali mau untuk melakukan kegiatan membaca selama adanya program literasi melalui pemberian bingo card.

\section{SIMPULAN}

Berdasarkah pemaparan hasil penelitian dan pembahasan pada penelitian yang berjudul "Implementasi Program Literasi Melalui Pemberian Bingo Card Untuk Menumbuhkan Minat Baca Pada Siswa Kelas III SDN Selorejo II" maka dapat disimpulkan sebagai berikut: Implementasi program literasi melalui pemberian bingo card pada siswa kelas III SDN Selorejo II dilakukan melalui 3 tahap yakni: a. Tahap pembiasaan, siswa diarahkan untuk membaca selama 15 menit sebelum pelajaran dimulai, b. Tahap pengembangan, tahap ini dilakukan dengan cara pemberian bingo card kepada siswa, c. Tahap pembelajaran, siswa mengerjakan pertanyaan yang ada pada kartu yang telah diambil dengan cara membaca dari berbagai media. Siswa yang telah selesai 
Evi, Rizka. Implementasi Program Literasi melalui... mengerjakan pertanyaan hingga terkumpul huruf $\mathrm{B}, \mathrm{I}, \mathrm{N}, \mathrm{G}, \mathrm{O}$ maka, siswa tersebut berhak mendapatkan hadiah. Minat baca siswa setelah adanya bingo card, dalam menyelesaikan bingo card siswa dituntut untuk dapat menyelesaikan tantangan perupa pertanyaan pada kartu-kartu yang diambil dari kantong-kantong bingo card hingga terkumpul huruf B, I, N, G, O. Pertanyaan tersebut hanya dapat dikerjakan dengan cara siswa membaca dari berbagai media terlebih dahulu. Jadi setelah adanya bingo card minat baca siswa mengalami pertumbuhan yang sangat bagus, dari yang tadinya siswa tidak mau membaca menjadi mau untuk membaca hingga 3-4 judul cerita sekaligus. Kedepannya agar pihak sekolah baik guru maupun kepala sekolah dapat menyosialisasikan program literasi melalui pemberian bingo card kepada semua guru khususnya di SDN Selorejo II agar dapat diimplementasikan dalam pembelajaran dan menaruh perhatian yang lebih kepada siswa dan dapat mengarahkan siswa untuk melakukan kegiatan berliterasi.

\section{UCAPAN TERIMA KASIH}

Terima kasih disampaikan kepada kepala sekolah SDN Selorejo II Kabupaten Lamongan yaitu Bapak Kasmanan, S.Ag., MM. dan guru SDN Selorejo II Kabupaten Lamongan yaitu Viva Dwi Madona, S.Pd,,yang telah memberikan kesempatan dan ketersediaan melakukan penelitian dalam kondisi pandemi Covid-19.

\section{DAFTAR RUJUKAN}

Abidin, Yunus, Tita Mulyati dan Hana Yunansah. 2017. Pembelajaran Literasi: Strategi Meningkatkan Kemampuan Literasi Matematika, Sains, Membaca, dan Menulis. Jakarta: Bumi Aksara.

Ahmadi, Farid \& Hamidulloh Ibda. 2018. Media Literasi Sekolah: Teori dan Praktik. Semarang: CV. Pilar Nusantara.

Antoro, Billy. 2017. Gerakan Literasi Sekolah: Dari Pucuk Hingga Akar Sebuah Refleksi. Jakarta: Direktorat Jenderal Pendidikan Dasar dan Menengah Kementrian Pendidikan dan Kebudayaan. 
Evi, Rizka. Implementasi Program Literasi melalui...

Budiharto, Triyono, \& Suparman. 2018. Literasi Sekolah Sebagai Upaya Penciptaan Masyarakat Pebelajar Yang Berdampak Pada Peningkatan Kualitas Pendidikan. Ilmu Sejarah, Sosial, Budaya Dan Kependidikan, 5(1), 153-166.

Dharma, K. B. 2013. Implementasi Gerakan Literasi Sekolah dalam Menumbuhkan Minat Membaca Siswa di Sekolah Dasar. Journal of Chemical Information and Modeling, 53(9), 1689-1699. https://doi.org/10.1017/CBO9781107415324.004

Ghony, M. Djuanidi \& Fauzan Almanshur. 2012. Metodologi Penelitian Kualitatif. Jogjakarta: Ar-Ruzz Media.

Hastuti, S., \& Lestari, N. A. 2018. Gerakan Literasi Sekolah: Implementasi Tahap Pembiasaan Dan Pengembangan Literasi Di SD Sukorejo Kediri. Jurnal Basataka (JBT), 1(2), 29-34.https://doi.org/10.36277/basataka.v1i2.34

Hendrayanti, A. 2018. Peningkatan Minat Baca Dan Kemampuan Membaca Peserta Didik Kelas Rendah Melalui Penggunaan Reading Corner. Jurnal Penelitian Pendidikan, 17(3), 235-248.

Kemendikbud. 2019. Desain Induk Gerakan Literasi Sekolah. Jakarta: Direktorat Jendral Pendidikan Dasar dan Menengah Kementerian Pendidikan dan Kebudayaan.

Kusumaningrum, Vincentia Retno. 2019. Hubungan Program Gerakan Literasi Sekolah Dengan Minat Baca Dan Kemampuan Berfikir Kritis Siswa. Skripsi. Fakultas Keguruan dan Ilmu Pendidikan. Yogyakarta: Universitas Sanata Dharma. Diakses pada 10 Agustus 2020. http://repository.usd.ac.id/35280/2/141324018_full.pdf .

Maharani, O. D., Laksono, K., \& Sukartiningsih, W. 2017. Minat Baca Anak-Anak Di Kampoeng Baca Kabupaten Jember. Jurnal Review Pendidikan Dasar : Jurnal Kajian Pendidikan Dan Hasil Penelitian, 3(1), 320. https://doi.org/10.26740/jrpd.v3n1.p320-328

Malawi, Ibadullah, Dewi Tryanasari, dan Apri Kartikasari. 2017. Pembelajaran Literasi Berbasis Sastra Lokal. Magetan: CV. Ae Media Grafika.

Mulyati, Yeti, dkk. 2016. Bahasa Indonesia. Tanggerang Selatan: Universitas Terbuka.

Mutia, P., Atmazaki, \& Nursaid. 2018. Implementasi aktivitas literasi di sma negeri batusangkar. Jurnal Pendidikan Bahasa Dan Sastra Indonesia, 7(3), 257-266. 
Evi, Rizka. Implementasi Program Literasi melalui...

Ruslan, \& Wibayanti, S. H. 2019. Pentingnya Meningkatkan Minat Baca Siswa. Prosiding Seminar Nasional Pendidikan Program Pascasarjana Universitas PGRI Palembang 12 JANUARI 2019, 767-775.

Salma, A., \& Mudzanatun. 2019. Analisis Gerakan Literasi Sekolah Terhadap Minat Baca Siswa Siswa Sekolah Dasar. MIMBAR PGSD Undiksha, 122-127.

Setiawan, Roosie \& Sofie Dewayani. 2019. Seri Manual GLS Variasi kegiatan 15 menit Membaca di Sekolah. Jakarta: Direktorat Jenderal Pendidikan Dasar dan Menengah Kementerian Pendidikan dan Kebudayaan.

Suyono, Harsiati, T., \& Wulandari, I. S. 2017. Implementasi Gerakan Literasi Sekolah Pada Pembelajaran Tematik Di Sekolah Dasar. Suyono Titik Harsiati Ika Sari Wulandari Universitas, 26(2), 116-123.

Sudarsana, Undang \& Bastiano. 2017. Pembinaan Minat Baca. Tanggerang Selatan: Universitas Terbuka. 